\title{
Utility of Batang Toru River (North Sumatra, Indonesia) for fishery activities of the local communities: a study on fisheries socio- economic condition
}

\author{
Thomas Nugroho ${ }^{1, *}$, Charles P. H. Simanjuntak ${ }^{2}$, Sulistiono ${ }^{2 *}$, M. Fadjar Rahardjo ${ }^{2}$, \\ Dadang Shafrudin ${ }^{3}$, Totok Hestiranoto ${ }^{3}$, and Agus Joko Ismanto ${ }^{5}$ \\ ${ }^{1}$ Department of Fisheries Resources Utilization, Faculty of Fisheries and Marine Sciences, Bogor \\ Agricultural University, Bogor. 16680 \\ ${ }^{2}$ Department of Aquatic Resources Management, Faculty of Fisheries and Marine Sciences, Bogor \\ Agricultural University, Bogor. 16680 \\ ${ }^{3}$ Department of Aquaculture, Faculty of Fisheries and Marine Sciences, Bogor Agricultural \\ University, Bogor. 16680 \\ ${ }^{4}$ Department of Marine Sciences and Technology, Faculty of Fisheries and Marine Sciences, Bogor \\ Agricultural University, Bogor. 16680 \\ ${ }^{5}$ Department of Environment, PT North Sumatera Hydro Energy, Jl. Darmawangsa VII No 2, Jakarta, \\ 12160
}

\begin{abstract}
Batang Toru River is a river that crosses several sub-districts in North Tapanuli and South Tapanuli Regency and has social and economic benefits for the community. This study aimed to determine the fisheries' socio-economic condition of the community around the river. Study was carried out in August 2019, on the communities around the river in five districts, namely Sipirok district (Luat Lobang and Aek Batang Paya Village), Marancar District (Marancar Julu, Pasar Sempurna, Simaninggir, and Huraba Village), Batang Toru District (Sipenggeng and Hapesong Baru Village), Muara Batang Toru District (Bandar Hapinis Village), and Simangumban District (Simangumban Jae Village). The data collected were analyzed descriptively. Based on the study, the local communities usually used the river for fishing, although fishing was not their main occupation. The fish caught were generally for their consumption or sold in the surrounding village.
\end{abstract}

\section{Introduction}

With thousands of islands, Indonesia has large and small rivers spreading from the west to the east. Large rivers are found in some regions of Java, Sumatra, Kalimantan, and Papua. The rivers included the Batang Toru River, have a potential that the communities can utilize for various purposes. The Batang Toru River is a basic natural resource that plays an essential source of life for people. Water from the river is a place that saves abundant biodiversity and

\footnotetext{
* Corresponding author: thomasnu@apps.ipb.ac.id
} 
a good habitat for living various aquatic plants and animals; and also used to fulfill human needs such as livelihood; agricultural production, animal husbandry, fisheries, industry and energy, transportation, tourism, and other needs, all of which can contribute to the economic growth and thus can reduce poverty [1].

Communities and rivers have historical relationships that make a peculiar social life pattern influenced by river culture - that is, the communities' behavior in utilizing the river's function. Rivers have the function of providing transportation access before the opening of the routes to the land. Besides, rivers also have an economic function according to the physical condition of their environment that provides a variety of potentials that humans can exploit to encourage the economic activities of the communities around the rivers [2].

However, as long as an increasing population and rapid development process, the existence and function of the rivers face challenges due to behavior, habits, and other variables of socio-economic condition in the community. It is contributed to change orientation in utilizing and managing resources of the rivers. Thus, it requires an understanding of this matter.

Batang Toru River is administratively located in North Tapanuli and South Tapanuli Regencies with a length of about $174 \mathrm{~km}$ and empties into the Indian Ocean [3]. Batang Toru River is rich with fishery resources that important aspect of the river ecosystem. Several studies on fish and fisheries in the rivers have been carried out, i.e., in the Kelingi River (Lubuk Linggau, South Sumatera) [4], the Luk Ulo River (Kebumen, Central Java) [5], the Enim River (Muara Enim, South Sumatera) [6], and Bendo Village (Banyuwangi, East Java) [7]. However, until now, there has been no information related to the use of the river for the communities, especially in the Batang Toru River. Therefore, it is important to conduct a study on the use of the waters. The purpose of this study was to reveal the fishery's socioeconomic conditions of the communities around the Batang Toru River, especially the role of the river for the surrounding communities.

\section{Methods}

\subsection{Time and location}

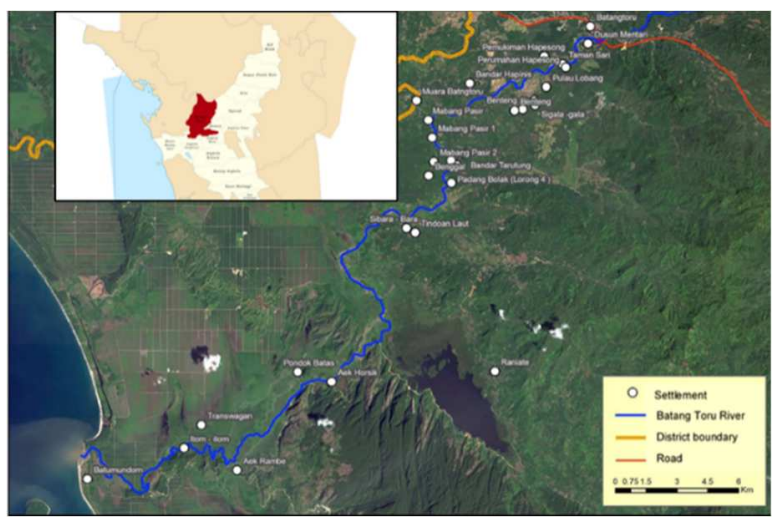

Fig. 1. The study area of the fisheries socio-economic conditions of local communities in relation to the use of the river for the surrounding communities.

This study on the fisheries' socio-economic condition relating to Batang Toru River utilization activities for the surrounding communities was conducted in August 2019. This 
study was carried out in 5 districts of 2 regencies (North Tapanuli and South Tapanuli), namely (1) Sipirok District (Luat Lobang and Aek Batang Paya Villages); (2) Simangumban District (Simangumban Jae Village); (3) Marancar District (Marancar Julu, Pasar Sempurna, Simaninggir, and Huraba Villages); (4) Batang Toru District (Sipenggeng and Hapesong Baru Villages); and (5) Muara Batang Toru District (Bandar Hapinis Village) (Figure 1).

\subsection{Data collection}

The kind of data used is primary data. The data in the form of information from the communities were collected using the focus group discussion (FGD) method, and interviews with respondents were carried out using a questionnaire with a list of questions that covered the characteristic of fishing activities in the river, the condition of fish resources, and the social and institutional condition. People who actively fish in the Batang Toru River were chosen as respondents. The respondents were determined by using the purposive sampling method with a total of 57 people. The data obtained were analyzed using Excel and described narratively.

\section{Results}

\subsection{General description of community activities at the study area}

This research observed people who live in ten villages around the Batang Toru River and their activities related to the river. First, Luat Lobang Village. This village has a hilly topography with a number population of around 1,204 persons. This village has three subvillages (Kampung) namely Pengkolan Village, Bulu Payung, and Hutaim Baru with 287 households. Of the three villages, only two villages are adjacent to Batang Toru River, namely Bulu Payung Village and Hutaim Baru. There are about ten persons who actively interact with the river and fish in Batang Toru River. In general, the main livelihood of people is as a farmer in the cultivation of rubber, coffee, cocoa, palm sugar, and vegetables such as chili.

Second, Aek Batang Paya Village. The village has a hilly topography which around 631 people inhabit. There are three sub-villages (kampung), namely Paske, Lake Lombang, and Gunung Hasahatan. Most people work as farmers in a paddy field, a plantation of tapping palm sugar, and traditional producer palm sugar. The rural people spend time working in a paddy field or a plantation from morning to evening. They also use part-time daily activities for fishing as additional work to meet the necessary animal protein of the family. To fish is done after they complete work in the field, but it is not routinely conducted. Though, there are sometimes a few people who sell wild fish in the surrounding village. Yet, most people are not dependent on the river as the main source of their income.

Third, Simangumban Jae Village. The village is a part of Simangumban District North Tapanuli Regency and is inhabited by around 2,325 people. This village has five sub villages namely Sipetang, Simajambu, Hexa, Parsanggrahan, and Banjar Nainggolan. Most people work as a farmer in the plantation of rubber, cultivation of sweet potatoes and paddy. Besides that, there are a few people who actively fish in the Batang Toru River. The fishing gear usually used by rural people is a handlines and a kind of bait prepared depending on a target of wild fishes wanted. The boiled sweet potato combined with garlic, palm fruit, and food coloring is bait to fish mahseer (local name Jurung). In contrast, a locust is employed as a bait to catch catfish (local name Baung). In addition, a fish trap is used to get fish as well. 
Fourth, Marancar Julu Village. The village has a hilly topography that roughly 986 persons populate. The main occupation of villagers is as a farmer in rice fields and plantations. Fishing in the river is generally carried out as a part-time or additional job. The fishing gears used are nets and fishing rods. The fish catches are usually mahseer (small or 50 fishes per kilogram with a selling value of around IDR 40 thousand per kilogram). If the fish catches are more than one kilogram, they will be sold, but they will be for their consumption less than half a kilogram. People usually go to the river to fish based on the weather conditions. When there is rain, they do not go to Batang Toru River because the water is not good and there is a lot of garbage. The fishing locations include Aek Sigumuruh, which is about 500 meters from the settlement. The time for the people who rest is usually at 10:00 pm, and they return to work at 07:00 am. The types of fish catches are mahseer (Tor spp.), Asian redtail catfish (Hemibagrus nemurus), bony lip barb (Osteochilus vittatus), other carps (Osteochilus spp.), and giant mottled eel (Anguilla marmorata).

Fifth, Pasar Sempurna Village. It has a hilly topography with a number population of around 1,808 persons. The main occupation of villagers is as a farmer in rice fields and farming of paddy, corn, beans, and vegetables such as chilies, cucumbers, leeks, long beans, water giant mottled eel, spinach, eggplants, and tomatoes. The fishing activity in the river is generally an additional part-time job to get money and meet protein needs. The fishing gears used are gillnets and handlines. Gillnets employed are sized from 2 to 3 fingers, while handlines used are usually those of numbers 4 and 5 . The bait used is a decay bait made from fermented cattle or goat's intestines that can be purchased at the nearest shop and market. The rotten bait is used for fishing Asian redtail catfish. The types of fish that villagers commonly catch are mahseer and Asian redtail catfish, and the wild fish catches are either sold or consumed by themselves.

Sixth, Simaninggir Village. This village has a hilly topography with around 868 persons consisting of 437 men and 431 women. The main occupation of villagers is as a farmer in rice fields and plantations of tapping palm trees. Activities of fishing in the river are generally as additional work. The fishing gears used are a gill net with a two-finger mesh size and a hand line. To fish with handlines uses two types of baits, namely grasshopper and earthworms. The fish caught in a gill net while still alive are put into "sange" (a basket made of rattan) with a capacity of 3-4 kilograms. Fishing activities using gill nets are conducted at night, and people usually spend a night in the river. The way that had been done is a gill net installed in the river and then left or waited in a camp overnight. The fish catches are usually small mahseer, Asian redtail catfish, and Cyprinid fishes.

Seventh, Huraba Village. It has a hilly topography lived in a population of approximately 871 persons. This village has three sub-villages (Kampung); the main occupation of the rural people is as a farmer in rice fields and plantations of rubber, cocoa, and sugar palm. Villagers generally conduct the activity of fishing in the river as an additional part-time job that is not only to get money and meet fish consumption and daily needs but also to refresh and hobbies. The kind of fishing gear used is a cast net and a handline. A place that is a fish destination is located around 1-2 km from home, and the farthest is $10 \mathrm{~km}$ away. The fish catches are usually Asian Redtail catfish as several 15 to 20 fishes or from 1.5 to 2.0 kilograms. The selling price of Asian Redtail catfish is from IDR 60,000 to IDR 70,000 per kilogram. Some fishing activities are carried out overnight in the river, and the catches are smoked or sold in the camp so that the fish do not rot. One kilogram of fresh Asian Redtail catfish fish, when smoked, will reduce its weight to 7 ounces. The selling price of smoked fish reaches IDR 120,000 per kilogram.

Then, eighth, Sipenggeng Village. This village has a flat topography with a population of around 1,207 persons. The main occupation of the villagers is as a farmer in rice fields and plantations of coffee, rubber, and sugar palm. Other agricultural products are contained palm 
oil and fruits, such as thorny alms, mangosteen, durian, and avocado. Many people fish in the river as their main occupation. The fishing gears used are gill nets and hand lines. The fishing activities are driven by the motivation to earn an income or to make a living. The activity of catching fish in the river is to get fish for consumption and collect fish seeds. The seeds of the jurung fish are collected using a scoop net. The fish seeds are collected at night in the river using a scoop net and a flashlight. The mahseer fish seeds are divided into four types: small mahseer, smaller mahseer, juvenile, and fry fish, which for breeding, are collected using hand lines (number 1 and 0.5 ) with a bait of palm fruit flesh that is chopped into small pieces. Palm fruit bait can also be used to catch Asian Redtail catfish, red-wing fish, and Tin-foil Barb fish.

Ninth, Hapesong Baru Village. It has a hilly topography, with a population of around 2,915 persons. This village has six sub villages namely Setianegara, Matahari, Nusa Indah, Taman Sari, Suka Maju, and Kemuning villages. The six villages are located near the river or around the banks of the Batang Toru River. The main occupation of the village community is farming (in rice fields and plantations - of rubber trees, cocoa, and sugar palm). Catching fish in the river is generally done as an additional part-time job; around 50 percent of the community fish to earn money and meet fish consumption and daily needs, and the rest 50 percent do it as a hobby and refresher. The fishing gears used are gill nets and hand lines. The fish caught are usually mahseer, Asian Redtail catfish, snakehead, cyprinids, and Indonesian shortfin eel (Anguilla bicolor). In addition to using hand lines, the community uses cash nets to catch fish, such as masher, bony lip barb, and yellowfin barb.

Tenth, Bandar Hapinis Village. The village has a flat topography with a population of around 1,109 people. Bandar Hapinis village has three sub-villages, namely Aek Sikkip Village, Lake Sigalas, and Karang Moncol. The main occupation of 80 percent of the communities in Aek Sikiip Village is fishing in the river. Thirty percent and 10 percent of the residents of Sub Village (Kampung) Danau Sigalas and Karang Moncol respectively do fishing as their main occupation. Other jobs in the three villages are mainly farming (in citrus, rubber, cocoa, and sugar palm plantations). However, some people make a living as entrepreneurs who collect fisheries products. Fishermen in Bandar Hapinis village go to the river every day to catch fish except on Fridays. The fishing location is $20 \mathrm{~km}$ from the housing. The fishing gears used are traps, hand lines, and gill nets. Eighty percent of fish catches are sold, and the rest are for their consumption. Fish species that are often caught in the waters of Bandar Hapinis are walking catfish, Asian redtail catfish, long whiskers catfish, tin-foil barb, giant gourami, mahseer, and snakehead.

\subsection{Socio-economic conditions of the community}

The communities actively engaged in fishing in the Batang Toru River can be categorized into four types based on the frequency of fishing activities every week. The first is fishing activities conducted every day (from Monday to Sunday), with only one day off on Friday or going fishing six days per week. The second one is the communities that often have a minimum of 3 days of fishing per week. Third, the communities who catch fish 1-2 days a week; and fourth, the communities who rarely do fishing or only have one fishing day in a week. The communities that actively do fishing in Batang Toru River mainly live in three districts, namely Sipirok, Marancar, and Batang Toru Districts, with an estimated 1.54 percent of the population (or around 215 people). The number of people who actively do fishing is presented in Table 1.

The river is utilized by various age groups of the local communities. The majority of people living around Batang Toru River who are engaged in fishing are in the age group above 40 years old. This shows that people who use the Batang Toru River are older 
generations aged between 43-50 and 59-66 years old. Interestingly, people in the age group 59-66 rank second as users of the rivers. This group consists of old farmers who use their spare time to fish for their consumption and retirees who have a hobby of fishing. People in the 30-40 years age group who are classified as productive age and do fishing activities are relatively small in number. The composition of the age groups of the local communities who do fishing in Batang Toru River is presented in Figure 2.

Table 1. The number of people who actively catch fish at Batang Toru River.

\begin{tabular}{|c|c|c|c|c|c|}
\hline $\begin{array}{c}\text { Location } \\
\text { (Subdistrict) }\end{array}$ & Village & $\begin{array}{c}\text { Number } \\
\text { of } \\
\text { people }\end{array}$ & $\begin{array}{l}\text { Number of } \\
\text { Subvillages }\end{array}$ & $\begin{array}{l}\text { Number of } \\
\text { households }\end{array}$ & $\begin{array}{l}\text { Estimated Total } \\
\text { Population } \\
\text { Actively Fishing } \\
\text { (percent) }\end{array}$ \\
\hline Simangumban & $\begin{array}{l}\text { Simangumbang } \\
\text { Jae (Sipetang) }\end{array}$ & 2325 & 5 & 539 & 0.43 \\
\hline \multirow[b]{2}{*}{ Sipirok } & Luat Lombang & 1204 & 3 & 287 & 0.83 \\
\hline & $\begin{array}{l}\text { Aek Batang } \\
\text { Paya }\end{array}$ & 631 & 3 & 154 & 1.58 \\
\hline \multirow{4}{*}{ Merancar } & Merancar Julu & 986 & 4 & 242 & 1.01 \\
\hline & Simaninggir & 868 & 3 & 210 & 1.15 \\
\hline & $\begin{array}{c}\text { Pasar } \\
\text { Sempurna }\end{array}$ & 1808 & 3 & 434 & 0.83 \\
\hline & Huraba & 871 & 3 & 218 & 1.15 \\
\hline \multirow{3}{*}{ Batang Toru } & Sipenggeng & 1207 & 2 & 247 & 4.14 \\
\hline & Hapesong Baru & 2915 & 6 & 678 & 0.34 \\
\hline & Bandar Hapinis & 1109 & 3 & 267 & 7.21 \\
\hline
\end{tabular}

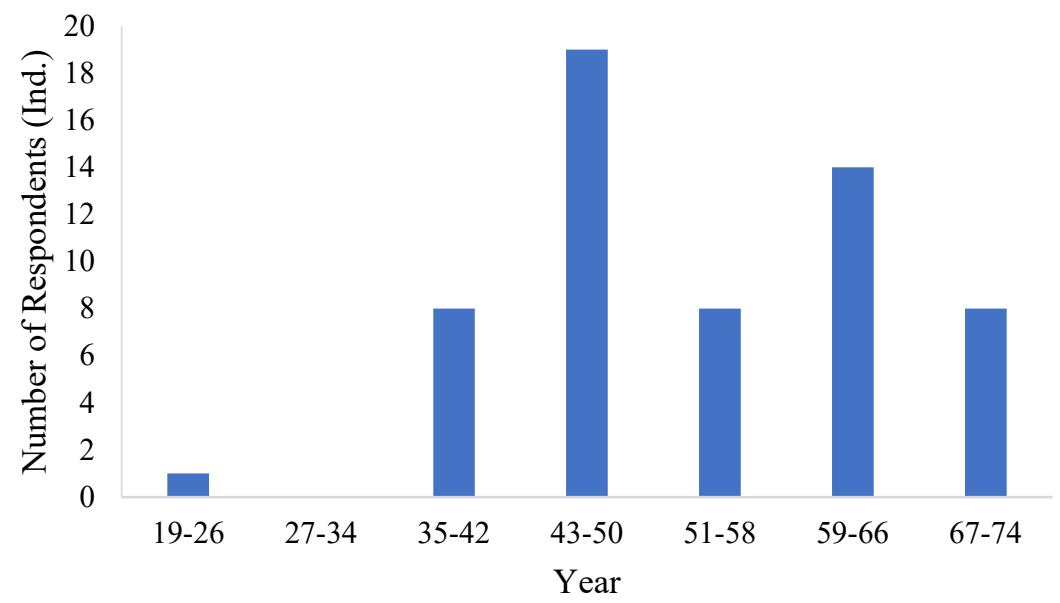

Fig. 2. Age group composition of the local communities fishing in Batang Toru River.

Most people living around the Batang Toru River earn a living as farmers or work in the agriculture and plantation sectors. Some other people work as employees or are self- 
employed in trading and work in an informal sector. However, from the study results in the field, some people have a strong bond with the river, use the river, and work as fishermen. From the study results on the communities that are also the respondents, it is known that 12 percent of the communities work as fishermen, 16 percent as entrepreneurs, and 72 percent as farmers. The composition of the livelihoods of the people catching fish in Batang Toru River is presented in Figure 3.

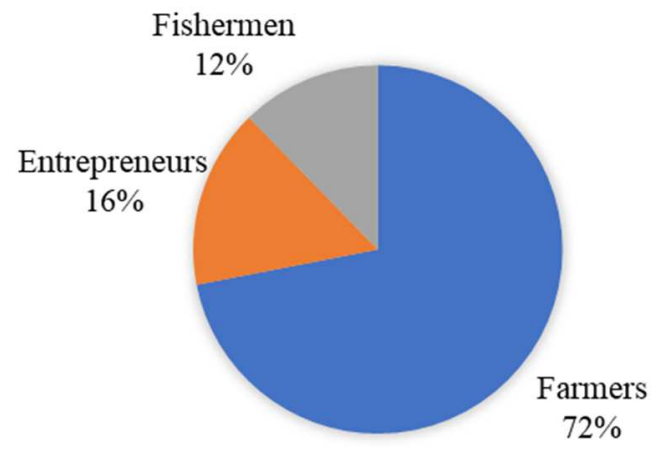

Fig. 3. Livelihood (main occupation) of the communities that catch fish at Batang Toru River.

The employment status of the people who fish in Batang Toru River is divided into three groups, namely fishing as the main work, the main part-time work, and additional part-time work. Fishing activities for earning money and meeting their basic daily needs are called basic or primary work. Fishing activities to increase their income and to meet basic daily needs are called the odd main job. Whereas fishing activities to earn extra money and not to fulfill daily basic needs are called additional part-time jobs. Based on field observations, it is known that fishing for most of the people who live around the Batang Toru River is not the main job but an additional part-time job. The distribution of the work status of the people who catch fish in Batang River is 16 percent as the main work, 17 percent as the main parttime job, and 67 percent as an additional part-time job. The distribution of the employment status of the people who catch fish in Batang Toru River is presented in Figure 4.

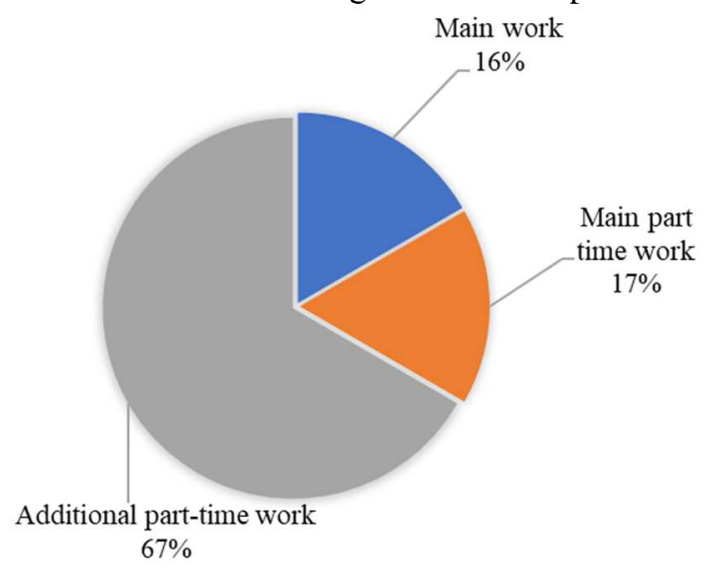

Fig. 4. Distribution of the work status of the people who catch fish in Batang Toru River.

\subsubsection{Characteristics of fishing activities in the river}


The frequency of community activities catching fish in Batang Toru River is relatively diverse, which is anytime, often, sometimes, and rarely. There is around 11 percent of people catch fish in the Batang Toru River every day. Meanwhile, an estimated 39 percent of the people catch fish frequently or at least three times a week. The community that catches fish occasionally or 1-2 times a week in Batang Toru River is around 42 percent. The number of people who rarely go to the river or only once a week to catch fish is 8 percent. The frequency of community fishing activities in Batang Toru River is presented in Figure 5. The distance of the fishing location from the place of residence or the one usually traveled by the communities falls into two categories, near and far. Close distance is less than $5 \mathrm{~km}$ or less than 30 minutes walk. While far distance is more than $5 \mathrm{~km}$ and takes more than 30 minutes to walk.

The fishing gear technology used by the communities is handline, gill net, cash net, and trap. 44 percent, 17 percent, 30 percent, and 9 percent use hand line, gill net, cash net, and fishing gear trap, respectively. The composition of the types of fishing gear used by the communities is presented in Figure 6 . The fishing gears used by the communities are obtained or purchased from a stall as much as 55 percent, then 23 percent are self-made, and 2 percent are bought in the market. This information shows that some people can make and provide their fishing gear to catch fish in the Batang Toru River.

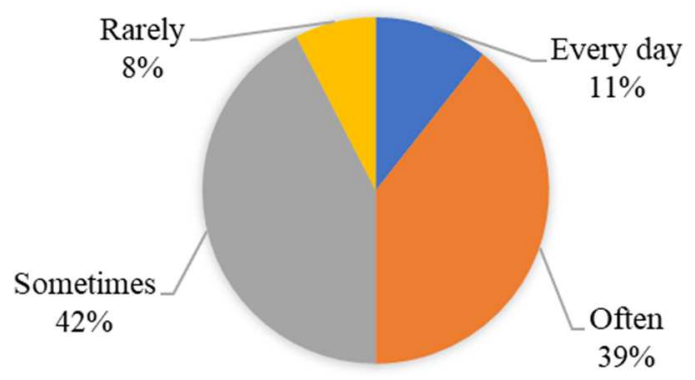

Fig. 5. Community fishing activities in Batang Toru River.

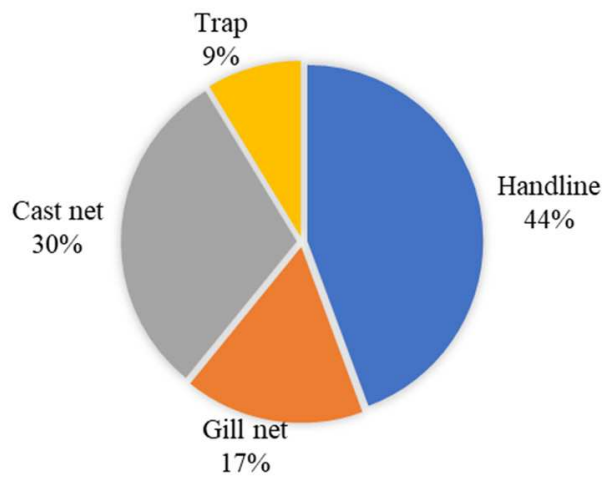

Fig. 6. Fishing gear composition used by the local community. 


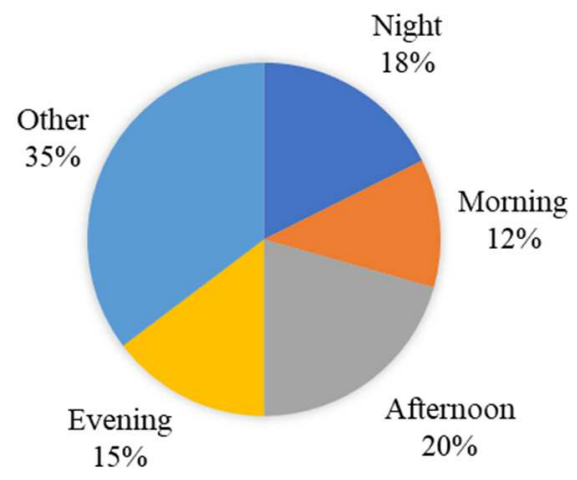

Fig. 7. Fishing time of the local communities.

The fishing time conducted by the communities is relatively diverse; some are carried out in the morning, and others in the afternoon, evening, night, and at uncertain or other times (Figure 7). The uncertain fishing time is relatively greater at 35 percent, and fishing time during the day and night, fishing time is 20 percent and 18 percent, respectively. Meanwhile, those who catch fish in the afternoon and morning are 15 percent and 12 percent, respectively.

There are at least 11 species of fish caught by the communities of The Batang Toru River, namely mahseer, Asian redtail catfish, bony lip barb, another barb (Osteochilus spp.), snakehead, yellowfin barb, walking catfish, giant gourami, long whiskers catfish, Indonesian shortfin eel, and swamp eel. The price of fresh fish caught by the people from Batang Toru River varies from IDR 20,000 to IDR 150,000 per kilogram. In addition to fresh fish, the local communities also process fish caught in the form of smoked fish. Smoked fish processing is usually done by the people who catch fish in the river for more than one day. The price of smoked fish marketed varies between IDR 40,000 and IDR 150,000 per kilogram. The types and prices of the fish market by the local communities are presented in Table 2.

Table 2. Kind and price of fish marketed by local communities

\begin{tabular}{|c|l|c|c|}
\hline No. & Kind of fish & Fresh fish (IDR/Kg) & Smoked fish (IDR/Kg) \\
\hline 1 & Small mahseer & 40,000 & \\
\hline 2 & Asian redtail catfish & 70,000 & 150,000 \\
\hline 3 & Mahseer & 150,000 & 40,000 \\
\hline 4 & Bonylip barb & 20,000 & \\
\hline 5 & Other barb (Osteochilus spp.), & 30,000 & \\
\hline 6 & Snakehead & 25,000 & 130,000 \\
\hline 7 & Yellow fin barb & 30,000 & \\
\hline 8 & Walking catfish & 30,000 & 60,000 \\
\hline 9 & Giant gourami & 50,000 & \\
\hline 10 & Long whispers catfish & 30,000 & \\
\hline 11 & Indonesian shortfin eel & 35,000 & \\
\hline 12 & Swamp eel & 35,000 & \\
\hline
\end{tabular}

The communities recognize the catching of fish in the Batang Toru River as uncertain or volatile. At least 12 factors were identified according to community recognition and could 
influence fish catching results, namely the number of fishers, weather, poisoning, the addition of seeds (restoking), overflowing/tidal water (floods), disruption to hydropower construction materials that resulted in turbidity of water's the river that could disturb a fish habitat, damaging activities, pollution, electricity shocking, subtle restrictions, garbage, and turbid (dirty) river water. Factors that influence fish catches are presented in Table 3.

Table 3. Factors that influence fish catches in Batang Toru River.

\begin{tabular}{|c|l|c|}
\hline No & Factors & $\%$ \\
\hline 1 & The number of fishermen & 6.98 \\
\hline 2 & Weather (rainy/dry season) & 13.95 \\
\hline 3 & Poison & 23.26 \\
\hline 4 & Restoking & 9.30 \\
\hline 5 & Flood & 11.63 \\
\hline 6 & Material disruption of hydropower development & 9.30 \\
\hline 7 & Damaging activities & 2.33 \\
\hline 8 & Pollution & 4.65 \\
\hline 9 & Electric shocking & 11.63 \\
\hline 10 & Lubuk larangan (reserve area) & 2.33 \\
\hline 11 & Lots of rubbish & 2.33 \\
\hline 12 & Turbid river water (dirty) & 2.33 \\
\hline
\end{tabular}

Although communities' dependence on Batang Toru River as a source of livelihood is relatively small, community fishing activities in the river tend to increase along with the number of residents who live around Batang Toru River. The communities catch fish in the Batang Toru River for various reasons, and these have the potential to suppress or affect the availability of fish resources in the river. Therefore, steps are needed to encourage people to switch from fishing to fish farming. There is around 49 percent of the communities have the desire to do aquaculture activities. This shows that the people around Batang Toru River are interested in conducting fish farming activities. Fish cultivation activities, namely carp cultivation, have been developing in three districts, namely Sipirok, Marancar, and Batang Toru Subdistricts. However, the farming of a local fish that is masher fish has yet to be developed because the communities have not been skilled with the cultivation techniques for this native fish species. There is only one person who can develop and cultivate the mahseer fish in Batang Toru District.

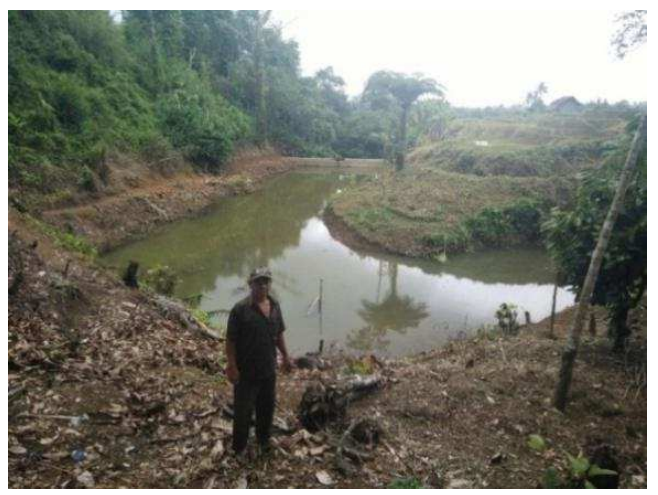

Fig. 8. The fish pond that is managed as a fishing pond (for recreational fisheries). 
Based on the observation in the field, there are fishing ponds that are cultivated by the community in Sugi Village, Marancar District. The types of fish that are cultivated are carp. As much as $50 \mathrm{~kg}$ of carp seeds have been purchased from the market for IDR 32,000 per kilogram since June 2019. The pond was built independently by the owner with a village fund. The cost of making the pond is around IDR 2 million.

\subsubsection{Fishery product marketing activities}

Batang Toru Market (Figure 9) is a trading center for various staples and community needs in Batang Toru District. The basic commodities that are traded include various types of fish caught by the people from the Batang Toru River. The marketed fish is in the form of fresh fish and processed fish. However, there are not many fish traders in the Batang Toru market. The results of the observation in the field show that there are three stalls selling fish, namely two stalls selling smoked fish and one stall selling fresh fish. Smoked fish available in the market come from around South Tapanuli Regency and also from outside South Tapanuli Regency. The main types of smoked fish that are marketed include catfish and lepan. The main fresh fish that are marketed are snakehead, catfish, eels, carp, etc.
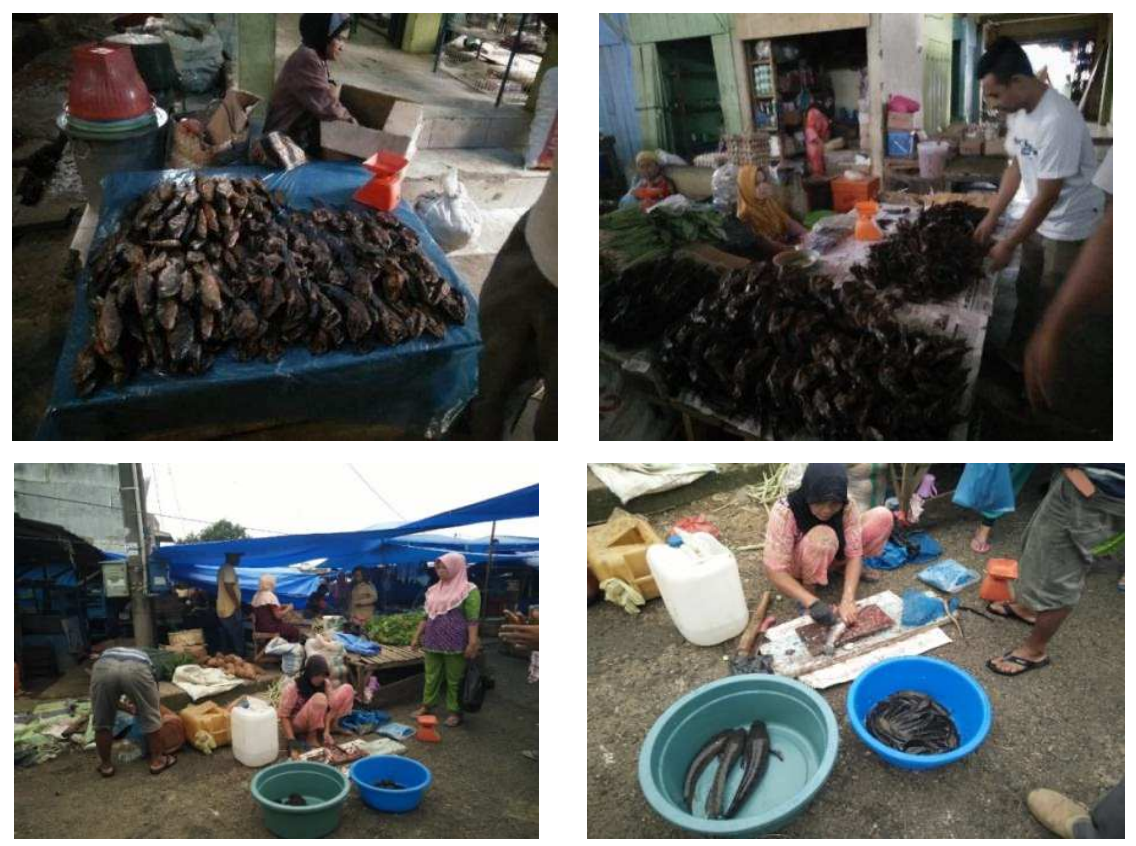

Fig. 9. Sellers of smoked and fresh fish in Batang Toru market.

The value of the sale of fish caught by the communities in the Batang Toru River is estimated at IDR 166.97 million per month. The biggest fish sales are in Sipenggeng Village and Bandar Hapinis in Batang Toru District, and in Pasar Sempurna Village, Marancar District. Estimated values of fishery products in three districts, namely Sipirok, Marancar, and Batang Toru Sub-districts, are presented in Table 4. 
Table 4. The estimated value of caught fish in Batang Toru River (IDR).

\begin{tabular}{|c|c|c|c|c|c|c|c|}
\hline Location & Villages & $\begin{array}{l}\text { Estimated number } \\
\text { of people fishing } \\
\text { actively (percent) }\end{array}$ & $\begin{array}{c}\text { Anytim } \\
\mathrm{e}\end{array}$ & Often & $\begin{array}{l}\text { Some } \\
\text { times }\end{array}$ & $\begin{array}{c}\text { Rarel } \\
\text { y }\end{array}$ & Total \\
\hline \multirow{2}{*}{$\begin{array}{c}\text { Simangu } \\
\text { mbang }\end{array}$} & $\begin{array}{l}\text { Simangumbang } \\
\text { Jae (Sipetang) }\end{array}$ & 0.43 & $\begin{array}{r}1,999,0 \\
00\end{array}$ & $\begin{array}{r}3,188 \\
, 250\end{array}$ & $\begin{array}{r}2,289 \\
, 000\end{array}$ & $\begin{array}{r}1,090 \\
, 000\end{array}$ & $\begin{array}{r}7,766 \\
, 250\end{array}$ \\
\hline & Luat Lombang & 0.83 & $\begin{array}{r}1,999,0 \\
00\end{array}$ & $\begin{array}{r}3,188 \\
, 251\end{array}$ & $\begin{array}{r}2,289 \\
, 001\end{array}$ & $\begin{array}{r}1,090 \\
, 001\end{array}$ & $\begin{array}{r}7,766 \\
, 251\end{array}$ \\
\hline Sipirok & $\begin{array}{c}\text { Aek Batang } \\
\text { Paya }\end{array}$ & 1.58 & $\begin{array}{r}1,999,0 \\
00 \\
\end{array}$ & $\begin{array}{r}3,188 \\
, 252 \\
\end{array}$ & $\begin{array}{r}2,289 \\
, 002 \\
\end{array}$ & $\begin{array}{r}1,090 \\
, 002\end{array}$ & $\begin{array}{r}7,766 \\
, 252 \\
\end{array}$ \\
\hline \multirow{4}{*}{ Merancar } & Merancar Julu & 1.01 & $\begin{array}{r}1,999,0 \\
00 \\
\end{array}$ & $\begin{array}{r}3,188 \\
, 253 \\
\end{array}$ & $\begin{array}{r}2,289 \\
, 003 \\
\end{array}$ & $\begin{array}{r}1,090 \\
, 003 \\
\end{array}$ & $\begin{array}{r}7,766 \\
, 253 \\
\end{array}$ \\
\hline & Simaninggir & 1.15 & $\begin{array}{r}1,999,0 \\
00 \\
\end{array}$ & $\begin{array}{r}3,188 \\
, 254\end{array}$ & $\begin{array}{r}2,289 \\
, 004\end{array}$ & $\begin{array}{r}1,090 \\
, 004\end{array}$ & $\begin{array}{r}7,766 \\
, 254 \\
\end{array}$ \\
\hline & Pasar Sempurna & 0.83 & $\begin{array}{r}1,798,5 \\
00 \\
\end{array}$ & $\begin{array}{r}4,782 \\
, 375 \\
\end{array}$ & $\begin{array}{r}3,433 \\
, 500 \\
\end{array}$ & $\begin{array}{r}1,635 \\
, 000\end{array}$ & $\begin{array}{l}11,64 \\
9,375\end{array}$ \\
\hline & Huraba & 1.15 & $\begin{array}{r}1,999,0 \\
00 \\
\end{array}$ & $\begin{array}{r}3,188 \\
, 250 \\
\end{array}$ & $\begin{array}{r}2,289 \\
, 000 \\
\end{array}$ & $\begin{array}{r}1,090 \\
, 000 \\
\end{array}$ & $\begin{array}{r}7,766 \\
, 250 \\
\end{array}$ \\
\hline \multirow{3}{*}{$\begin{array}{c}\text { Batang } \\
\text { Toru }\end{array}$} & Sipenggeng & 4.14 & $\begin{array}{r}5,995,0 \\
00 \\
\end{array}$ & $\begin{array}{l}15,94 \\
1,250\end{array}$ & $\begin{array}{l}11,44 \\
5,000\end{array}$ & $\begin{array}{r}5,450 \\
, 000\end{array}$ & $\begin{array}{l}38,83 \\
1,250\end{array}$ \\
\hline & Hapesong Baru & 0.34 & $\begin{array}{r}1,199,0 \\
00 \\
\end{array}$ & $\begin{array}{r}3,188 \\
, 250 \\
\end{array}$ & $\begin{array}{r}2,289 \\
, 000 \\
\end{array}$ & $\begin{array}{r}1,090 \\
, 000 \\
\end{array}$ & $\begin{array}{r}7,766 \\
, 250 \\
\end{array}$ \\
\hline & Bandar Hapinis & 7.21 & $\begin{array}{r}9,592,0 \\
00 \\
\end{array}$ & $\begin{array}{l}25,50 \\
6,000 \\
\end{array}$ & $\begin{array}{l}18,31 \\
2,000 \\
\end{array}$ & $\begin{array}{r}8,720 \\
, 000 \\
\end{array}$ & $\begin{array}{l}62,13 \\
0,000 \\
\end{array}$ \\
\hline \multicolumn{3}{|c|}{ Estimation of caught fish per month (IDR) } & $\begin{array}{r}25,778 \\
500\end{array}$ & $\begin{array}{c}68,54 \\
7,37\end{array}$ & $\begin{array}{c}49,21 \\
3,50\end{array}$ & $\begin{array}{c}23,43 \\
5,00\end{array}$ & $\begin{array}{r}166,9 \\
74,37 \\
5\end{array}$ \\
\hline \multicolumn{3}{|c|}{$\begin{array}{l}\text { Estimation of caught fish on average per month per } \\
\text { capita (IDR } / \text { month } / \text { kapita) }\end{array}$} & $\begin{array}{r}1,090,0 \\
00 \\
\end{array}$ & $\begin{array}{c}817,5 \\
00 \\
\end{array}$ & $\begin{array}{c}545,0 \\
00 \\
\end{array}$ & $\begin{array}{l}1,362 \\
, 500\end{array}$ & $\begin{array}{r}776, \\
625 \\
\end{array}$ \\
\hline
\end{tabular}

\subsubsection{Social and institutional conditions}

The social life of the communities around Batang Toru River adheres to values, norms, and rules that apply to both formal and informal contexts. Customary rules play an important role in influencing the communities' behavior in interactions between fellow community members and the environment around the river. Customary rules also become a source for formal rules that apply in the communities. The communities stated that around 55 percent of customary rules had been formalized into regional and village regulations (Figure 10).

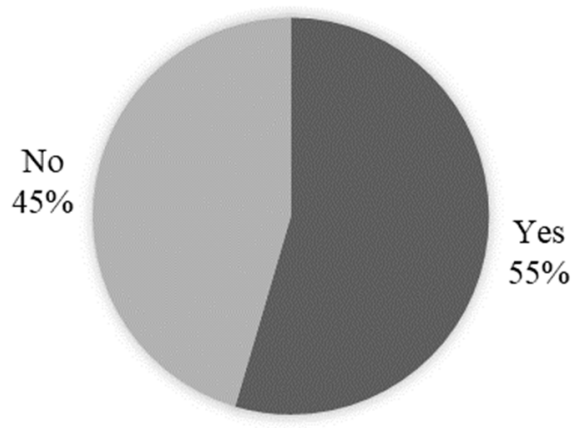

Fig. 10. Customary rules that have been formalized. 
Conflicts have occurred in fishing activities in the Batang Toru River. Based on the observations in the community, 39 percent of respondents said there had been conflicts, and 61 percent said there have never been conflicts. Conflicts that have occurred were caused by six factors, namely fishing areas, spatial use, mining wastewater disposal, use of fishing gear, regulations, and fish found poisoned. Conflicts that occur due to fishing grounds are as much as 9 percent; conflicts that occur due to space utilization are as much as 4 percent; conflicts that occur due to disposal of mine wastewater are as much as 5 percent; conflicts that occur due to the use of fishing gear are as much as 36 percent; conflicts that occur due to regulations are as much as 32 percent, and conflicts that occur as a result of fish caught by poison are as much as 14 percent. The information above shows that fishing gear causes the majority of conflicts related to fishing activities. The types of conflicts in fishing activities in Batang Toru River are presented in Figure 11.

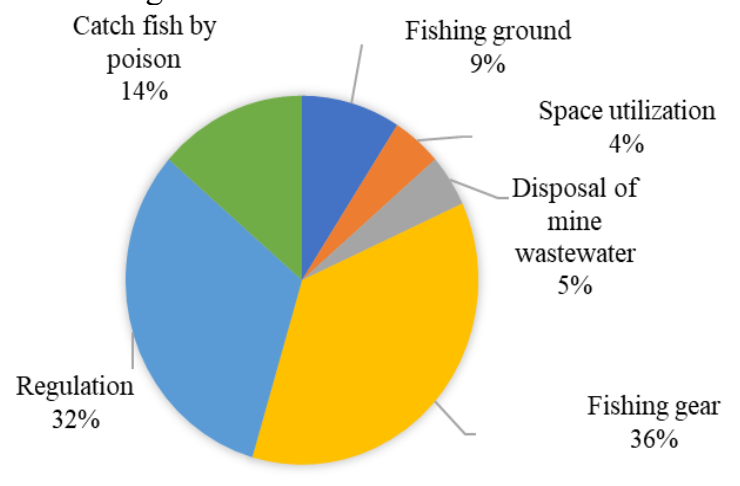

Fig. 11. Types of conflicts occurred in Batang Toru River.

The communities around Batang Toru River view that customary rules have benefits (Figure 12) which include protecting the environment so that it is not damaged, protecting fish, being very fortunate or benefit recipients, deterring destructive actors, and avoiding eating poisonous fish. People who feel the benefits of customary rules to protect the environment so as not to damage are as many as 18 percent; people who feel the benefits of customary rules so that fish are protected are as many as 55 percent; people who feel the benefits of customary rules as very lucky are as many as 9 percent; people who feel the benefits of customary rules to deter destructive actors are as many as 9 percent, and people who feel the benefits of customary rules so as not to eat poisonous fish are as many as 9 percent. The above views show that most people feel the benefits of traditional rules that are to protect fish. 


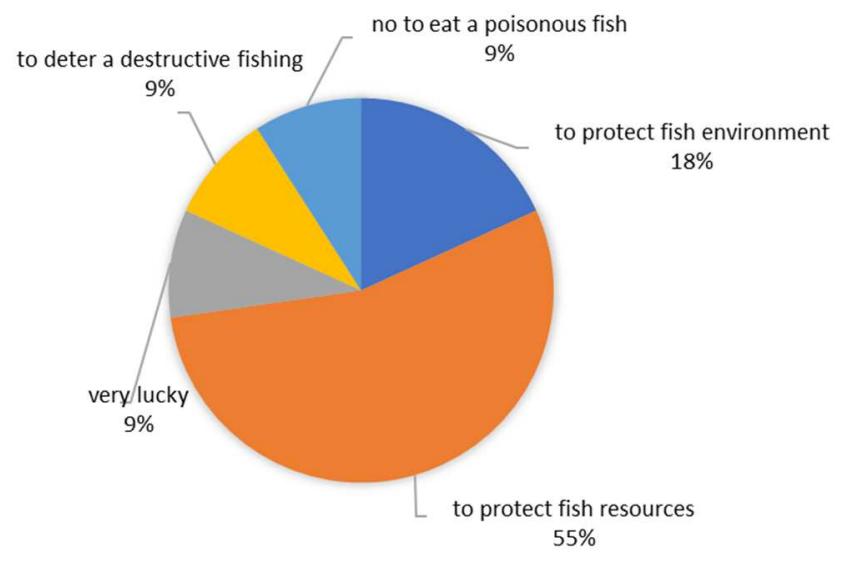

Fig. 12. Benefits of traditional rules for the local communities in Batang Toru River.

There are at least three kinds of traditional rules (Figure 13), which prohibit people from poisoning fish, using electricity, and carelessly using bombs to catch fish. People who agree with the customary rules to prohibit people from poisoning fish are 60 percent; people who agree with the customary rules to prohibit people from using electricity are as many as 20 percent, and people who agree with the customary rules that they should not catch fish carelessly using bombs are as many as 20 percent. This information shows an awareness from the majority of the communities of the need for customary rules to protect and conserve fish resources in the Batang Toru River.

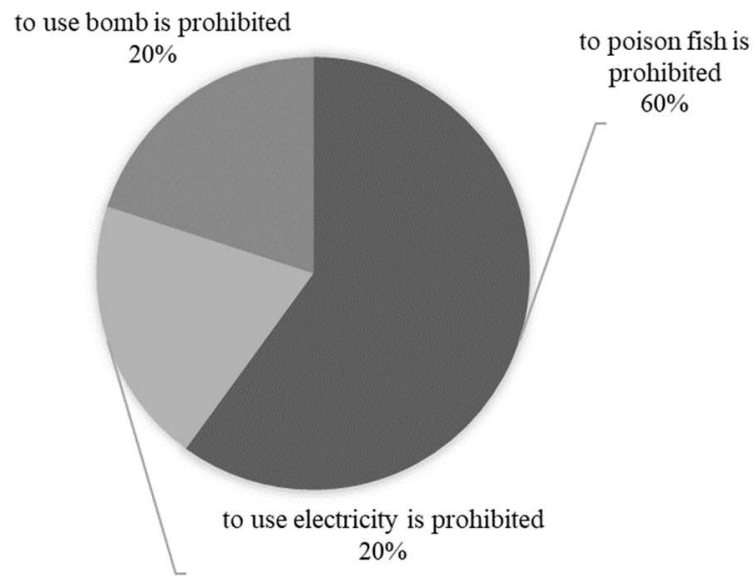

Fig. 13. Customary rules for the utilization of fish resources in Batang Toru River.

\section{Discussion}

Rivers play an important role in the lives of local communities in Kalimantan, along the Kapuas River basin. It has become the location of settlements and centers of community life activities such as industry, hotels/lodging, mining, malls (shopping centers), and transportation. However, this is not the case in the region of Batang Toru River. The steep 
topography (especially in the northern part of the Marancar District) does not allow the area to become a residential area. Nevertheless, in the vicinity of Batang Toru Subdistrict to the south, there are many community settlements.

As in some regions in Indonesia, rivers become fishing grounds and can generate income for the communities such as Musi River in Palembang [8], Suhui River in East Kutai [9], Mahakam River in East Kalimantan [10], and Barito River [11]. Likewise, the Batang Toru River is used as a location for fishing activities for additional income sources and tourism activities. People use areas that vehicles can access (motorbikes, cars) with a little slope as a tourist facility. Whereas other areas that are a bit steep are used as a fishing location for spreading nets, installing traps, or installing nets.

The closer the communities downstream or to the estuary is, the busier the fishing activities will be. To some members of the village communities, working to catch fish in the river is the main work. Some fishing activities are carried out overnight in the river, and the fish caught are smoked or sold near the fishing location and then marketed to other cities or regions. These conditions can be found in Aek Sikip, Muara Opu, and Batu Mundom Villages. In the upstream areas (such as in Huta Imbaru and Luat Lombang Village), only 13 people are actively fishing in the river using hand lines and gill nets. The fish obtained is only enough for their consumption.

In general, fishing activities in the Batang Toru River are not the main occupation and source of income for the communities. But to some residents, fishing in the river is the main occupation and the main source of income. The number of residents whose main job is fishing in Batang Toru River is not big, only about 1.54 percent of the total population of the ten villages observed. Nevertheless, the impact of the use of the Batang Toru River by the communities needs to be observed, especially activities that can reduce the quality of water and the quality of the river, such as turbidity, especially in rainy seasons.

The turbidity of river water is caused not only by degrading forest conditions but also by sand mining activities around Batang Toru River. Sand mining activities are found in the Bandar Tarutung area and also in the Huta Imbaru area. With high sedimentation and turbidity, the fish will not be able to live.

The activities of utilizing the potential of Batang Toru River by the community illustrate that humans cannot stop their dependence on nature. The potential possessed by the Batang Toru River can determine the pattern of community interactions with the river environment. Although the interaction pattern benefits people's lives, some things should not be ignored concerning the potential impacts arising from river resource utilization activities that damage the natural balance and ignore the community's values, norms, and rules.

The number of people who live around the river can pressure the condition of fish resource stocks in the Batang Toru River. The trend of increasing population and high population density can raise the level of community competition in utilizing the river's potential as a livelihood that is catching fish and as a fishing entertainment/tourism [12]. In addition, other social dynamics that occur and those that follow, including changes in community behavior in utilizing the potential of rivers, can have unexpected impacts, namely declines in the function of the river for people's lives.

Changes in environmental balance around Batang Toru River can occur due to an error in how the communities view the environment. The perspective that adheres to the anthropocentrism ethics that places human interests above or even sacrifices non-human interests, such as natural resources and the environment, becomes the root of the ecological or environmental crisis [13]. Such a perspective makes humans tend to behave toward chauvinism or think of themselves and ignore the interests of non-humans. This is reflected in the exploitative behavior of the communities in utilizing natural resources and the environment, including rivers. 
Therefore, community awareness is needed to change people's behavior towards the surrounding nature; natural resources and the environment (ecosystem) are integral part that is inseparable from the human life system, so they must be maintained [14]. The positive thing that was found from the results of this study was that the people around Batang Toru River realized that the behaviors that were not friendly to the river's resources and environment were the factors that could influence the catch of the fish. Such unfriendly behaviors include poisoning fish; dumping waste, garbage, solid material into the river, using electricity to catch fish; and other damaging activities.

Customary norms, values, and rules, which are the source of local wisdom of the communities, are important instruments that need to be maintained as a force in maintaining the balance of relations between the socio-economic and environmental interests of Batang Toru River. The Dayaks practice these in fishing in Sabangau River in Sabangau National Park area of Central Kalimantan [15]. Interactions between the communities and the natural environment, as well as interactions among members of the communities, including changes in orientation and interest in utilizing the potential of Batang Toru River, are part of a dynamic process in the social-ecological system that needs to be examined and identified as important information bases so that the impact can then be analyzed [16].

The utilization of rivers in the perspective of a social-ecological system reflects the occurrence of critical interactions between humans and rivers and complex interactions between the engineering, ecological, economic, and social domains [17]. Therefore, in response to changes in orientation and community interest in Batang Toru River, which can cause social friction or lead to conflict, a multidisciplinary approach to science is needed to overcome it.

The observations in this study identified five types of potential conflicts related to fishing activities in Batang Toru River, namely fishing areas, spatial use, mine wastewater disposal, use of fishing gears, and regulations. This river use conflict shows that the river has various functions. This is a characteristic of the rivers in Indonesia. In West Kalimantan, the Kapuas River is used as a space for bathing, washing, fishing, aquaculture, and water source for households, industry, agriculture, waste and garbage disposal, gold mining, sand, and transportation [18].

Although the communities have an instinct or potential as well as adaptability in responding to changes in the river environment due to natural or anthropogenic factors, capacity building in a broader perspective is also needed, such as negotiation and collaboration within the communities or civil society and also outside the communities such as with government institutions and private sectors. Thus, the communities are expected to be able to build strong local institutions and develop collective awareness and broad participation to preserve and maintain the natural function of the river. Therefore, the activities of utilizing the potential of Batang Toru River by the communities need to be directed to be managed inclusively with an integrative approach with due regard to interdisciplinary science and changes in the communities' interests and expectations [17].

Internalization of the concept of values and non-anthropocentric ethics or the value of ecosystems in the society also becomes important in maintaining the existence of local institutions, such as the depth of prohibitions. Lubuk larangan (reserve area) is a form of local wisdom that can be built and endured by the strength of social capital in society, namely intrinsic and instrumental values that affect human views and behavior toward the environment.

Intrinsic value is a value sourced or given by ecosystems by the philosopher Immanuel Kant as human rationality in maintaining sustainability and quality of life not only in the present but also in the future [19]. While instrumental value is the value of existence or usefulness as a means to an end. This instrumental value also includes the value of spirituality 
that can encourage the behavior to be obedient and willing to replace or pay for losses to ensure ecosystems and environmental resources remain available and sustainable.

The strength of social capital, such as maintaining trust, commitment, solidarity, harmony, caring, and others, comes from a society's intrinsic and instrumental values. The strength of social capital can maintain the depth of prohibitions in caring for and protecting the river's resources and environment. Conversely, weak social capital in the community can eliminate the role and existence of lubuk larangan as it occurs in Batang Toru tributary, the Aek Pardomuan River located in Pardomuan Village, Mandailing Natal District [20].

\subsection{Conclusion}

Batang Toru River holds huge natural resource potentials and plays a very important role in the socio-economic life of the surrounding communities. One river potential that is utilized by the community is fisheries resources. The communities utilize fisheries resources in the Batang Toru River to meet fish consumption needs and also bring additional income to the communities through fishing activities. Besides that, Batang Toru River has an attraction that can encourage the interest of the communities in conducting fishing tourism activities. This river utilization activity requires awareness and efforts to harmoniously establish interaction between the communities and the river. Therefore, actualizing and institutionalizing local wisdom values are needed to maintain and preserve the functions and benefits of the river for the people's lives in a sustainable manner. Based on the study, the local communities usually used the river for fishing, but it was not their main occupation. The fish caught were generally for their consumption or sold in the surrounding villages.

\section{References}

1. H. Parker, N. Oates, Working Paper 430, 1-73 (2016)

2. Rochgiyanti, J. Komunitas (in Bahasa Indonesia) 3, 51-59 (2013)

3. BPS South Tapanuli Regency in Figures (in Bahasa Indonesia) (BPS Tapanuli Selatan, North Sumatera, 2018)

4. D. Sumitra, Z. F. Rozi, J. Biota 4, 1-6 (2018)

5. T. T. Wahyuni, A. Zakaria, Biosfera 35, 23-28 (2018)

6. Hamidah, J. Iktiologi Indones. 4, 51-55 (2004)

7. H. Kenconojati, BDS. Suciyono, M.F. Ulkhaq, Agroveteriner 5, 89-97 (2016)

8. S. Koeshendrajana, O. Cacho, Fisheries (Bethesda) 2001, 2 (2001)

9. R.A. Nugroho, Y.G.G. Santoso, F.M. Nur, N. Hariani, S. Solikin, Aquac. Aquar. Conserv. Legis. 9, 345-351 (2016)

10. I. Suyatna, M. Syahrir, M. Mislan, Y.I. Wijaya, A. Abdunnur, Omni-Akuatika 13 (2017)

11. Hartatik, Naditira Widya 11, 149-164 (2017)

12. S. Funge-Smith, A. Bennett, Fish Fish 20, 1176-1195 (2019)

13. H. Kopnina, H. Washington, B. Taylor, J.J. Piccolo, J. Agricultural Env. Ethics 31, 109127 (2018)

14. L. Oosterbeek, I. Scheunemann, Cadernos Do LEPAARQ 10, 20 (2013)

15. E.F. Elbaar, L.M. Limantara, Int. J. Geomate 16, 78-85 (2019)

16. S.A. Purwanto, Forests Trees and Livelihoods 27, 141-157 (2018)

17. J. Sendzimir, P. Magnuszewski, L. Gunderson, Riverine Ecosystem Management: Science for Governing Toward a Sustainable Future 8, 301-324 (Amsterdam, Springer 
International Publishing, 2018)

18. M.C. Lukas, Julia, I. Radjawali, M. Flitner, O. Pye, Austrian J. South-East Asian Stud. 5, 359-368 (2012)

19. T.J. Pitcher, Fish and Aquatic Resources Series (2011).

20. C. Kristopel, Undergraduate Thesis 2018, 132 (2018) 